ISSN: 2146-3042

DOI: $10.25095 /$ mufad.937725

\title{
COVID 19 Sürecinde Üniversitelerde Uzaktan Muhasebe Eğitiminin SWOT Analiz Tekniği İle Değerlendirilmesi*
}

\section{ÖZET}

Bu çalışmada COVID 19 salgınının yaratmış olduğu kriz döneminde özellikle muhasebe ĕ̆itiminde, uzaktan eğitim sisteminin yaratmış olduğu yeni ĕgitim şeklinin güçlü yönleri, zayıf yönleri, firsatları ve tehditlerini (SWOT analizi) tespit etmek amacı bulunmaktadır. Bu amaç doğrultusunda, Adıyaman Üniversitesinde ögrenim gören İktisadi ve İdari Bilimler Fakültesi ve Sosyal Bilimler MYO Issletme ve Kooperatif Programlarında muhasebe dersi alan 406 ögrenci üzerinde bir anket uygulaması yapılarak elde edilen veriler üzerinde SWOT analizi ve SPSS 15 programı ile "t testi", "Anova testi" analizi yapılmıştır. Katılımciların cinsiyet, program türü, yaşadıkları yer, dersteki başarı düzeyleri, eğitime katılım sağladıkları teknoloji türüne göre güçlü, zaylf, firsat ve tehdit boyutlarında yer alan ifadelere katılımlarında farklılıklar tespit edilmiştir. Açık uçlu soru ile elde edilen veriler doğrultusunda ise, ögrencilerin uzaktan muhasebe derslerindeki eğitim sistemine yönelik görüşlerine ve önerilerine yer verilmiştir.

Anahtar Kelimeler: Muhasebe, Uzaktan Eğitim, COVID 19

JEL Sinıflandırması: M41,I23,I21

\section{Evaluation of Distance Accounting Education in Untversities with SWOT Analysis}

\section{Technique in COVID19 Process}

\section{ABSTRACT}

In this study, it is aimed to determine the strengths, weaknesses, opportunities and threats (SWOT analysis) of the new education style created by the distance education system, especially in accounting education, during the crisis caused by the COVID 19 disease. In line with this purpose, a questionnaire was conducted on 406 students studying at Adyaman University Faculty of Economics and Administrative Sciences and Social Sciences Vocational School of Business and Cooperative Programs by conducting a questionnaire on the data obtained by using SWOT analysis and "t test", "Anova test" with SPSS 15 program. "Analysis has been done. Differences were determined in the participants' participation in the expressions in the dimensions of strength, weakness, opportunity and threat according to their gender, program type, place of residence, their success level in the course, and the type of technology they participated in the training. In line with the data obtained with an open-ended question, students' opinions and suggestions about the education system in distance accounting courses were included.

Keywords: Accounting, Distance Learning , COVID 19

Jel Classification: M41,I23,I21

\footnotetext{
* Makale Gönderim Tarihi: 15.05.2021, Makale Kabul Tarihi: 03.08.2021, Makale Türü: Nicel Araştırma Makaledeki anket çalışmasının, Adıyaman Üniversitesi Sosyal ve Beşeri Bilimler Etik Kurulu'nun 16.02.2021 tarihli 66 sayılı toplantısında, etik açıdan uygun olduğuna karar verilmiştir.

** Dr. Öğr.Üyesi, Adıyaman Üniversitesi, yezin@adiyaman.edu.tr, ORCID: 0000-0001-8068-6927.
} 


\section{GíRiş}

COVID 19 salgının ölümcül bir hastalık olması dolayısıyla Dünya Sağlık Örgütü pandemi kararı almıştır. Alınan pandemi kararı ile birlikte ortaya çıkan kısıtlamalar küresel ekonomiyi derinden etkilediği gibi eğitim alanında da büyük değişimlere yol açmıştır. Yeni oluşan düzende, alışılagelmiş olan eğitim sistemi değişmiş ve tüm eğitimcileri uzaktan eğitim sistemi aracılığıyla eğitim vermeye mecbur kılmıştır. Ülkemizde de Yükseköğretim kurulu kararı doğrultusunda tüm üniversiteler genel olarak eğitim faaliyetlerini uzaktan eğitim sistemine dönüştürmüştür. 2019-2020 Bahar dönemi ve 2020-2021 güz döneminin tamamı ve bir sonraki yarıyıl için ise yüz yüze eğitim ve öğretim düzenine geçilmesi halen belirsizdir. Daha önce bu kadar uzun süreli karşılaşılmamış pandemi süreci, eğitim sisteminden maksimum fayda sağlamak için uzaktan eğitim sistemlerine, ders içeriklerine, altyapı ve uygulamalarına, yönetim ve finansman gibi alanlara yatırımların yönlendirilmesi gerekliliği ortaya çıkmıştır (Can, 2020:11).

Kısitlamaların gündeme gelmesi ile birlikte 16 Mart 2020 tarihinden itibaren ülkemizde de uzaktan eğitim sistemine geçiş süreci başlamıştır. Bu süreçte öğrenciler ve akademisyenler ile internet tabanlı sinıflar üzerinden canlı dersler, ders videoları, ders materyalleri, ödev ve sınav bilgileri gibi eğitime yönelik tüm unsuların yer aldığı platformlar ve programlar üniversiteler tarafından kullanılmaya başlanmıştır. Kaliteli bir uzaktan eğitim sisteminin yaratılabilmesi için gerekli unsurların başında bir politika belirlenmesi ve bununla birlikte altyapı oluşturulması, erişim olanakları, kullanım yeterliliği, eğitim ve öğretim süreci, uzman insan kaynağı, destek hizmetleri, bilgi güvenliği ve etik boyutlar yer almaktadır (https://portal.yokak.gov.tr/makale/uzaktan-egitim-ve-kalite-guvence-sistemi/).

COVİD19 virüsünün dünyada sadece eğitim sektörü için değil tüm sektörler için krize sebep olduğu bir süreç ortaya çıkmıştır. Ancak bilindiği üzere Çince krizin "tehdit" ve "fırsat" olarak iki ayrı anlamı bulunmaktadır. Pandemi dönemi ile birlikte karşılaşılan bu kriz dönemi, eğitim sektöründe oluşan olumsuzluklara rağmen uzaktan eğitim ile bir firsat ortamı yarattığ söylenebilir. Her sektörde olduğu gibi önemli olan, kriz anında tehlikenin farkında olmak ve aynı zamanda fırsatları da görebilmektir (Stoller, 2020:748).

$\mathrm{Bu}$ çalışmada yapılan literatür taraması sonucunda bir anket geliştirerek elde edilen veriler aşağıda belirtilen amaçlar doğrultusunda ele alınmıştır.

1. Uzaktan eğitim sisteminin muhasebe dersi alan öğrenciler açısından Güçlü Yönler, Zayıf Yönler, Fırsatlar ve Zorluklar (SWOT) yönünden analizini yapmak,

2. Katılımcıların demografik özelliklerine göre SPSS 15.0 programı aracılığıyla, ankette yer alan güçlü, zayıf, firsat ve tehdit boyutlarına göre farklılıklarının olup olmadığını tespit etmek,

3. Katılımcıların uygulanan uzaktan eğitimde muhasebe derslerine yönelik görüşlerini tespit etmek 


\section{UZAKTAN EĞITIM UYGULAMASI TANIMI VE ÖZELLİKLERİ}

Uzaktan eğitim öğrenmedeki tarafların birbirinden zaman ve mekân olarak ayrı kaldığı (Aydın 2011:53), TDK'ya göre belirli bir merkezden iletişim araçları ile yapılan eğitim sistemidir. Bilgi akışının öğreticiden öğrenene doğru sağlandığı bu uygulamalar da başarılı bir sistemden bahsedilebilmesi için sistem kalitesi, servis kalitesi, bilgi kalitesi, memnuniyet ve kullanım faydası hususları önem arz etmektedir (DeLone ve McLean, 1992:94).

Wedyemer'e göre uzaktan eğitim sisteminin taşıması gereken on temel özellik şu şekilde sıralanmaktadır (Nizam, 2004:2);

- Öğreticiye ihtiyaç olmadan, istenilen zaman ve mekânda çalışılabilmeli,

- Ögrencilere derslerle ilgili daha fazla sorumluluk verilmeli,

- Öğrenenlerin başarısını artırabilmek için öğreticiler daha fazla zaman ayırmalı,

- Öğrenenlere derslerle ilgili formatlar ve yöntemlerle ilgili olanaklar sunulmalı,

- Eğitim programlarına uygulanabilecek öğretim metotları ve yöntemleri geliştirilmeli,

- Konu anlatımında anlaşılırlığı artırmak için farklı yöntemler ve ortamlar kullanılmalı,

- Derslerin içerikleri geliştirilmeli,

- Öğrenenler arasındaki bireysel farklılıkları göz önünde bulundurarak olanaklar sunulmalı,

- Öğrenenlerin başarılarının değerlendirilmesindeki zaman, yöntem, faaliyet sıralaması gibi faktörler ortadan kaldırılmalı,

- Öğrenenlerin çalışmayı başlayıp tamamlamaları için özgür bırakılmalıdır.

\section{SWOT ANALIZI}

Durum analizi olarak bilinen SWOT (güçlü yönler (Strengths), zayıf yönler (Weaknesses), firsatlar (Opportunities) ve tehditler (Threats) analizi, hem iç (güçlü ve zayıf yönler) hem de diş (firsatlar ve tehditler) faktörleri değerlendirmek için kullanılmaktadır (Weihrich 1982:55). Eğitim kurumlarının, eğitim sonunda beklenilen kazanımların değerlendirilmesi ve tespit edilen noksanlıklara yönelik stratejiler geliştirilmesi için yapılması gereken durum tespitini ancak SWOT analizi tekniği ile yapabilmektedir (Özan vd., 2015:2).

$\mathrm{Bu}$ nedenle üniversitelerde COVID 19 döneminde eğitim sürecindeki şimdiki durumun analizi ve gelecek planlaması yapabilmek için SWOT analizi belirleyici olmaktadır. Şekil 1' de uzaktan eğitim sisteminin yaratmış olduğu güçlü, zayıf, firsat ve tehdit durumları gösterilmektedir.

\begin{tabular}{|l|l|}
\hline Güçlü Yönler & Zayıf Yönler \\
\hline *Zaman ve mekan esnekliği & *Teknik zorluklar \\
*Geniş Kitleye Ulaşabilme & *Öğrenenlerin kapasitesi ve öğrenme düzeyi \\
*Ders içeriklerine rahat ulaşım & *Zaman Yönetimi \\
*Geri bildirimin çabuk olması & *Dikkat dağınıklı̆ı̆ hayal kırıklı̆̆ı, endişe ve \\
& $\begin{array}{l}\text { kafa karışıllı̆̆ } \\
\text { *Kişisel/fiziksel ilgi eksikliği }\end{array}$ \\
\hline Fırsatlar & Tehditler \\
\hline
\end{tabular}




\begin{tabular}{l|l} 
*İnovasyon ve dijital gelişim alanı & *Bilgi ve teknoloji altyapısının eşitsiz (adil \\
*Esnek programlar tasarlanması & olmayan) dağılımı \\
*Beceriler kazanmak: İnovasyon ve dijital & *Eğitim kalitesi \\
problem çözebilme kapsamı, eleştirel & *Dijital okuryazarlık \\
düşünebilme ve uyum sağlayabilme & *Dijital bölümlendirme \\
*Her yaştan kullanıcıların olması & *Teknoloji maliyeti ve eskime \\
*Yenilikçi bir pedagojik yaklaşım (eğitimin her & \\
alanında radikal dönüşüm) & \\
\hline
\end{tabular}

Şekil 1. Kriz dönemlerinde çevrimiçi öğrenmenin SWOT Analizi

Kaynak: Dhawn, 2020:14

Özellikle sadece COVID19 krizi değil, diğer afet ve olağandışı kriz dönemlerinde de zayıf ve tehdit unsurlarının giderilmesi ve aynı zamanda firsat unsurlarının değerlendirilmesi yönünde öğretme-öğrenme sürecinin tespiti konusunda SWOT analizi sonuçlarının iyi yönetilmesi ve yorumlanması önem arz etmektedir.

\section{LITERATÜR TARAMASI}

Yapılan literatür araştırmasında öğrenci ve eğitimcilerin karşılaştıkları yeni dönemde, eğitim açısından olumlu ve olumsuz birçok yön ortaya çıkmıştır. Öğrenciler açısından olumlu yönler arasında video tekrarı, zaman tasarrufu, esnek eğitim şartları görülmekte iken olumsuz olarak eğitime ulaşabilmedeki internet bağlantısı sorunları tespit edilmiştir (Serçmeli ve Kurnaz,2020: 53). Akademisyenler açısından ise, uzaktan eğitim sürecinde zaman ve mekanın esnek olması, yapılan çalışmaların kayıt altında olması, uzaktan eğitim sürecinin deneyimlenmesi, ögrencilerin ders için araştırma ve çaba harcaması aynı zamanda kaynaklara rahat ulaşabilmesi, maliyetin düşük olması bu sürecin olumlu yönleri iken, derse katılım azlığı ve düşük düzeylerde derse katılımların olması muhasebe derslerinde anlamayı zorlaştırdığ yönünde olumsuz görüşler bulunmuştur (Serçmeli ve Kurnaz 2020: 288).

Önemli unsurlardan bir diğeri de uzaktan olan bu eğitim sürecinde öğrencilerin eğitimcilerle iletişim kurabilmeleridir. Ancak örgün öğretime kıyasla bu süreçte iletişimde sorunlar olduğu ve bunun dışında öğrencilerin gelecek ile ilgili mesleklerine katkı sağlayacak bir kalitede eğitim almadıklarını ifade etmektedirler (Akgün, 2020: 236). Bu olumsuzluklara rağmen, uzaktan eğitimin en büyük kolaylıklardan biri notlara erişim, zamanı verimli kullanabilme ve ders takibinin daha rahat olması yönünde olumlu veriler de bulunmaktadır (Afşar ve Büyükdoğan 2020:161).

Karadağ ve Yücel (2020) çalışmasında, uzaktan eğitim sürecinde Türkiye'de bulunan 163 üniversite üzerinde öğrenim gören 17.939 lisans öğrencisi üzerinde anket çalışması yürütmüştür. Yapılan anket uygulamasında Yüksek Öğretim Kurulu'nun bu süreçte yapmış olduğu bilgilendirmelerden ve uygulamalarından öğrencilerin çoğu memnunken, üniversitelerin ve fakültelerin aynı şekilde bilgilendirmelerinden, uzaktan eğitime tutum ve yaklaşımlarından benzer bir sonuç ortaya çıkmamıştır. Aynı şekilde Dijital eğitim ve öğretimde kullanılan yöntem ve materyaller ile ders videoları ile ilgili memnuniyet düzeylerinin de oldukça düşük olduğu ortaya çıkmıştır.

Dhawn (2020) çalışmasında, doğal afetler ve kriz dönemlerinde eğitim kurumları için önem arz eden çevrimiçi öğrenme sistemleri aracılı̆̆ ile öğrenmenin önemi ve bu kriz anlarında kullanılan uzaktan eğitim sistemlerinin güçlü yönleri, zayıf yönleri, firsatları ve 
zorlukları (SWOT) analizini yapmıştır. Yapılan araştırma sonucunda özellikle pandemi sürecinde uzaktan eğitim sisteminin, zaman ve mekan esnekliği güçlü yön olarak belirtilirken, zaman yönetimi, dikkat dağınıklığı, personel yetersizlikleri zayıf yönlerinden bazıları olarak tespit edilmiştir. Dijital yeniliklerde gelişim gösterilmesi bir firsat alanı oluştururken, eğitim kalitesi ise bu sürecin tehditleri arasında göze çarpmaktadır.

Ayyıldız vd. (2006) çalışmasında da ayrıca örgün eğitimin kazandıracağı kültür ve sosyalleşmenin sağlanamaması uzaktan eğitimin en önemli dezavantajı olarak görmekte olup, öğrenciler arasındaki kişisel öğrenme farklılıkları ve yeni bilgi öğrenmedeki kişisel farklılıklarında dikkate alınması gerekliliği üzerinde durmuştur.

Kurnaz vd. (2020), dijitalleşmenin muhasebe eğitimi uygulamalarındaki etkisini meslek mensupları açısından ele alan bir çalışma yapmışlardır. Elde edilen bulgularda yükseköğretim kurumlarında verilen muhasebe eğitimlerinin hem teknolojiye hem de uluslararası gelişmelere uyum sağlamadığı ve digital sistemlerle ilgili yetersizliklerin olduğunu tespit etmişlerdir.

Yardımcıoğulları vd. (2021) çalışmalarında ise; COVID-19 sürecinde Meslek Yüksekokulu öğrencilerinin muhasebe eğitimine karşı tutumlarını incelediğinde gelecek planlamalarında meslek sahibi olabilecekleri muhasebe ile ilgili olarak, derslerin eğlenceli ve aynı zamanda motive edici olarak buldukları ancak ders çalışırken kaygılı oldukları tespit edilmiştir.

Yapılan literatür araştırmasında özellikle uzaktan eğitim sisteminde muhasebe derslerine yönelik çalışmaların sınırlı olduğu görülmektedir. Bu çalışmayla, COVİD19 sürecinde uzaktan eğitimde muhasebe derslerine yönelik durum tespitinin istatiksel analiz ile birlikte değerlendirilmesinden dolayı literatüre katkı sağlayacağı düşünülmektedir.

\section{ARAŞTIRMANIN METODOLOJISİ}

\subsection{Araştırmanın Amacı}

Araştırmanın amacı üniversite öğrencilerinin uzaktan eğitim sürecinde muhasebe eğitiminin kendilerine sağlamış olduğu katkıların SWOT analizi ile tekniği ile değerlendirilmesidir. Bu amaç doğrultusunda uzaktan eğitim sisteminin öğrencilere muhasebe eğitimi anlamında öğrencilere sağlamış olduğu güçlü yanları ve firsatlara karşın, zayıf ve tehdit yaratan yanlarını da belirleyebilmektir. Ayrıca uzaktan yapılan muhasebe eğitiminin SWOT analizi ile oluşturulan alt faktörlere (güçlü, zayıf, tehdit ve firsat) öğrencilerin cinsiyet, yaşanılan yer, eğitimde kullanılan teknoloji, program türü, sınıf düzeyi ve ders başarı değişkenlerine göre analiz sonucu verilerin incelenmesidir.

$\mathrm{Bu}$ araştırma ile Adıyaman Üniversitesi lisans programı olarak İktisadi ve İdari Bilimler Fakültesi, Sosyal Bilimler Meslek Yüksekokulu programlarında muhasebe dersi alan öğrencilerin öncelikli olarak demografik özellikleri belirlenmiş ve uzaktan muhasebe derslerine yönelik anket çalışması sonuçları değerlendirilmiştir. 


\subsection{Veri Toplama Aracı}

Araştırmada veri toplama aracı olarak anket uygulamasına yer verilmiş olup, Dhawn'ın (2020) çalışmasında yapmış olduğu SWOT analizi sonuçları ile, Serçmeli ve Kurnaz'ın (2020) çalışmasında kullanmış olduğu anket çalışması göz önünde bulundurularak yeni bir anket geliştirilmiştir. Kullanılan ankette oluşturulan ifadeler de 5'li Likert ölçeği kullanılarak elde edilen veriler doğrultusunda geçerlilik güvenirlik analizleri yapılmıştır.

Anketin birinci kısmında, katılımcıların demografik özelliklerini belirlemek amacı ile 6 adet soru sorulmuştur. Ayrıca ankette, katılımcıların muhasebe dersine yönelik algılarını tespit etmek amaciyla 1 adet soru bulunmaktadır. İkinci kısımda ise katılımciların Uzaktan eğitim sisteminde muhasebe derslerine yönelik düşüncelerini belirlemek amaciyla 19 ifadeden oluşan "Uzaktan Eğitimde Muhasebe Dersi Durum Ölçeği”, 5'li Likert ölçeği (1 -Kesinlikle Katılmiyorum, 2-Katılmıyorum, 3-Fikrim Yok, 4-Katılıyorum, 5-Kesinlikle Kat1liyorum) kullanılarak ölçülmüştür. Ankette bulunan ifadeler Dhawn $(2020,14)$ çalışmasında ki SWOT sonuçları dikkate alınarak "güçlü, zayıf, fırsat ve tehdit" olarak dört alt faktör şeklinde belirlenmiştir. Anketin uygulamaya konulmasından önce Adıyaman Üniversitesi Sosyal ve Beşeri Bilimler Etik Kurulundan gerekli izinler alınmıştır.

\subsection{Araştırmanın Yöntemi ve Kapsamı}

Çalışmada kullanılan anketin uygulamasında Google form ile oluşturulan e-anket formu muhasebe dersi alan öğrencilere uygulanmıştır. Özellikle 2020-2021 Güz döneminde muhasebe dersi alıp, güz dönemini bitiren öğrenciler ve bahar döneminde muhasebe dersi alan öğrenciler üzerinde araştırma yapılmıştır. Verilerin değerlendirilmesinde ise SPSS 15.0 programından yararlanılarak, istatistiksel analizler kapsamında betimleyici analizler, frekans, yüzde dağılımları, t testi, Anova ve Tukey testleri uygulanmıştır.

Bu kapsamda İktisadi ve İdari Bilimlerde İktisat, İşletme, Kamu Yönetimi bölümleri ile Sosyal Bilimler Meslek Yüksekokulu'nda Muhasebe ve Vergi Uygulamaları, İşletme Yönetimi, Kooperatifçilik, Dış Ticaret bölümlerinde zorunlu genel muhasebe dersleri zorunlu olarak yer aldığından programlarda yer alan öğrencilerin toplam sayısı 1893 kişiden oluşmaktadır. Araştırmanın örneklemini, 2020-2021 Güz ve Bahar yarıyıllarında Adıyaman Üniversitesi lisans programı olarak İktisadi ve İdari Bilimler Fakültesi, Sosyal Bilimler Meslek Yüksekokulu programlarında muhasebe dersi alan basit tesadüfi örneklem yöntemi ile 406 öğrenci oluşturmaktadır.

Uygulanan ölçeğin geçerlilik ve güvenilirliğin tespiti açısından öncelikli olarak 69 öğrenci üzerinde bir deneme çalışması yapılmış olup, anketin uygulanabilirliği açısından bazı sorular çıkartılmış ve tekrardan düzenlenen anket 415 kişi üzerinde uygulanmıştır. Ancak uygulama sonrasında eksik ve hatalı anketler çıkartıldıktan sonra geriye kalan 406 anket değerlendirmeye alınmıştır.

\section{ARAŞTIRMA BULGULARI}

Katılımcıların demografik özelliklerine ait bilgiler çalışmanın giriş kısmında yönlendirilmiş olup, bu bilgilere ait elde edilen verilerin sonuçları aşağıdaki tablolarda ayrıntılı olarak gösterilmiştir. 


\subsection{Demografik Özellikler} gösterilmiştir.

Katılımcı sayısının 406 olduğu çalışmaya ait demografik bilgiler Tablo 1' de

Tablo 1. Katılımcıların Cinsiyet, Yer ve Kullanılan Teknoloji Dağılımı

\begin{tabular}{lcc}
\hline Cinsiyet & Sayı & Oran(\%) \\
\hline Kadın & 209 & 51,5 \\
Erkek & 197 & 48,5 \\
Toplam & 406 & 100,0 \\
\hline Yaşanılan Yer & Sayı & Oran (\%) \\
\hline İl & 233 & 57,4 \\
İlçe & 83 & 20,4 \\
Köy & 90 & 22,2 \\
Toplam & 406 & 100,0 \\
\hline Eğitim için kullanlan teknoloji & Sayı & Oran (\%) \\
\hline Bilgisayar & 145 & 35,7 \\
Tablet & 11 & 2,7 \\
Cep telefonu & 250 & 61,6 \\
Toplam & 406 & 100,0 \\
\hline
\end{tabular}

Katılımcıların demografik özellikleri incelendiği zaman çalışmadaki kadın katılımcıların 209 kişi $(\% 51,5)$, erkek katılımcıların ise $197(\% 48,5)$ kişi olarak birbirine yakın değerlerde katılım sağladığı görülmektedir. Katılımcıların uzaktan eğitim sürecinde yaşadıkları yer incelendiğinde 233 kişi $(\% 57,4)$ il, 83 kişi $(\% 20,4)$ ilçe ve 90 kişi $(\% 22,2)$ köy olarak tespit edilmiştir. Ayrıca katılımcılardan 250 kişinin $(\% 61,6)$ cep telefonu, 11 kişinin $(\% 2,7)$ tablet ve 145 kişinin $(\% 35,7)$ bilgisayar ile eğitime katıldıkları görülmektedir.

Tablo 2. Katılımcıların Öğrenim Programı, Sınıf Düzeyi ve Muhasebe Dersi Genel Başarısı Dağılımı

\begin{tabular}{lcc}
\hline Öğrenim Programı & Sayı & Oran(\%) \\
\hline Önlisans & 190 & 46,8 \\
Lisans & 216 & 53,2 \\
Toplam & 406 & 100,0 \\
\hline Sınıf & Sayı & Oran (\%) \\
\hline 1. sınıf & 184 & 45,3 \\
2. sınıf & 137 & 33,7 \\
3. sınıf & 8 & 2,0 \\
4. sınıf & 77 & 19,0 \\
Toplam & 406 & 100,0 \\
\hline Muhasebe Derslerindeki & Sayı & Oran (\%) \\
Genel Başarı & & \\
\hline Pekiyi (85-100) & 37 & 9.1 \\
Iyi (75-84) & 87 & 21,4 \\
Orta (70-74) & 162 & 39,9 \\
Şartlı Başarılı (60-69) & 70 & 17,2 \\
Başarısız (0-59) & 50 & 12,3 \\
Toplam & 406 & 100,0 \\
\hline
\end{tabular}


Katılımcılardan 216 kişi $(\% 53,2)$ lisans programında öğrenim görmekteyken, 190 kişi $(\% 46,8)$ ön lisans programında öğrenim görmektedir. Sınıf düzeyleri ise incelendiğinde 184 kişi (\%45,3) 1. sınıf, 137 kişi (\%33,7) 2.sınıf, 8 kişi (\%2) 3.sınıf ve 77 kişi (\%19) 4.sınıf öğrencilerinden oluşmaktadır. Katılımcıların muhasebe derslerindeki genel not durumu incelendiğinde ise; çoğunluk olarak 162 kişi $(\% 39,9)$ orta, 87 kişi $(\% 21,4)$ iyi, 37 kişi $(\% 9,1)$ pekiyi not ortalamalarına sahipken, geri kalan 120 kişi $(\% 29,5)$ ise şartlı başarılı ve başarısız öğrencilerden oluşmaktadır.

\subsection{Katılımcıların Uzaktan Eğitimde Muhasebe Dersine Olan Algıları}

Katılımcıların uzaktan eğitim sırasında muhasebe eğitimine yönelik algılarına ilişkin bilgiler Grafik 1’de görülmektedir.

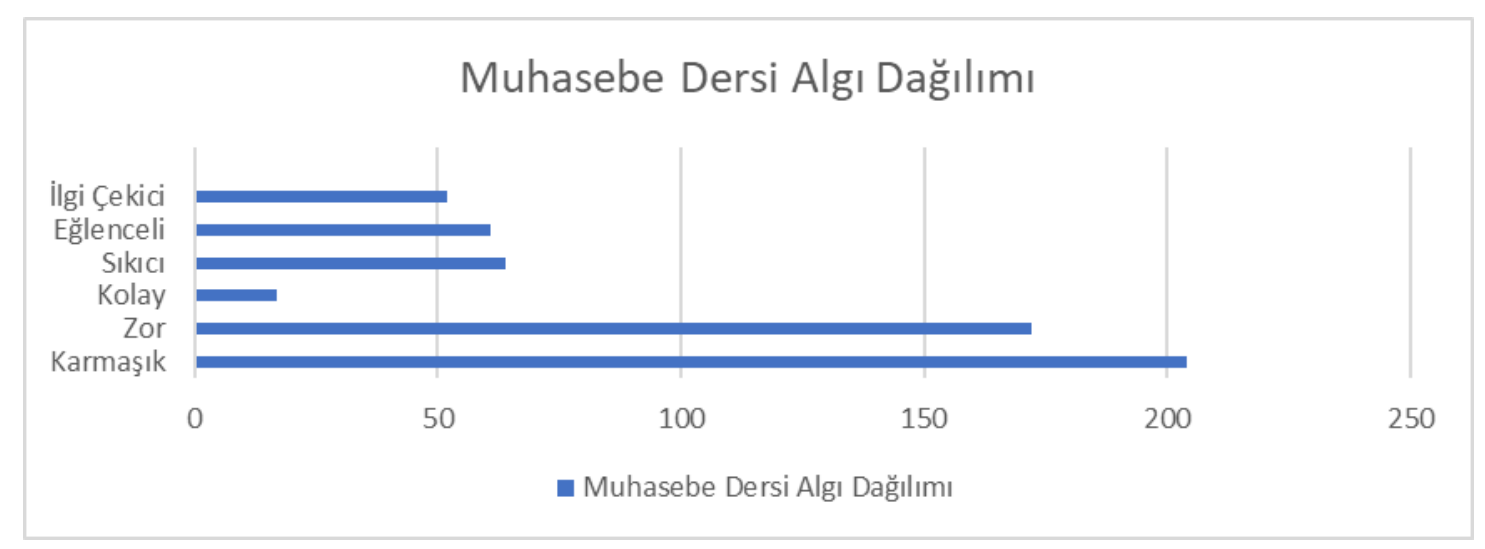

Grafik 1. Uzaktan Eğitimde Muhasebe Dersi Alg1 Dağılımı

Katılımcılar ifadelerinde birden fazla seçenek işaretlemiştir. Elde edilen veriler sonucunda; 204 kişi karmaşık, 172 kişi ise muhasebe dersinin uzaktan eğitimde zor olduğunu ifade etmiştir. Muhasebe dersinin kolay olduğunu ifade eden katılımcının ise sadece 17 gibi az sayıda olduğu görülmektedir. Muhasebe dersini sıkıcı bulan katılımcı sayısı 64 kişi iken, eğlenceli bulan kişi sayısı ise 61 olarak tespit edilmiştir.

\subsection{Ortalama Dağılımları ve SWOT Analizi Sonuçları}

Katılımcıların ankette yer alan ifadelere katılım oranlarının tespiti için ortalama dağılımları göz önünde bulundurulmuştur. Elde edilen veriler aşağıdaki tabloda özetlenmiştir. 
Tablo 3. Uzaktan Eğitimde Muhasebe Dersi Durum Ölçeği Ortalama Dağılımları

\begin{tabular}{|c|c|c|c|c|c|c|c|}
\hline \multirow[t]{2}{*}{ İfadeler } & \multicolumn{4}{|c|}{$\begin{array}{c}\text { İfadelerin Dağı̆ımı } \\
\text { n (\%) } \\
\end{array}$} & \multirow[b]{2}{*}{$\begin{array}{c}5 \\
(\%)\end{array}$} & \multirow[b]{2}{*}{ Ort. \pm} & \multirow[b]{2}{*}{$S D$} \\
\hline & $\begin{array}{c}1 \\
(\%)\end{array}$ & $\begin{array}{c}2 \\
(\%)\end{array}$ & $\begin{array}{c}3 \\
(\%)\end{array}$ & $\begin{array}{c}4 \\
(\%)\end{array}$ & & & \\
\hline $\begin{array}{l}\text { 1. Muhasebe derslerine uzaktan eğim sürecinde } \\
\text { istediğim zaman ve mekânda girebilmekten memnunum }\end{array}$ & $\begin{array}{c}78 \\
(19,2)\end{array}$ & $\begin{array}{c}71 \\
(17,5)\end{array}$ & $\begin{array}{c}95 \\
(23,4)\end{array}$ & $\begin{array}{c}61 \\
(15,0)\end{array}$ & $\begin{array}{c}101 \\
(24,9)\end{array}$ & 3,09 & 1,444 \\
\hline $\begin{array}{l}\text { 2. Muhasebe derslerinde uzaktan eğitim sürecinde } \\
\text { eğitim/öğretim içerikli ders materyallerine } \\
\text { ulaşabilmekten memnunum }\end{array}$ & $\begin{array}{c}49 \\
(12,1)\end{array}$ & $\begin{array}{c}66 \\
(16,3)\end{array}$ & $\begin{array}{c}101 \\
(24,9)\end{array}$ & $\begin{array}{c}82 \\
(20,2)\end{array}$ & $\begin{array}{c}108 \\
(26,6)\end{array}$ & 3,33 & 1,344 \\
\hline $\begin{array}{l}\text { 3. Uzaktan eğitimde muhasebe derslerine yönelik } \\
\text { kaynak ve materyal (kitap, fotokopi vb.) maliyetlerimde } \\
\text { azalma olmuştur. }\end{array}$ & $\begin{array}{c}59 \\
(14,5)\end{array}$ & $\begin{array}{c}49 \\
(12,1)\end{array}$ & $\begin{array}{c}91 \\
(22,4)\end{array}$ & $\begin{array}{c}71 \\
(17,5)\end{array}$ & $\begin{array}{c}136 \\
(33,5)\end{array}$ & 3,43 & 1,426 \\
\hline $\begin{array}{l}\text { 4.Uzaktan eğitim sürecinde muhasebe ders videolarını } \\
\text { tekrarlarını izleyebilmekten memnunum }\end{array}$ & $\begin{array}{c}30 \\
(7,4)\end{array}$ & $\begin{array}{c}32 \\
(7,9)\end{array}$ & $\begin{array}{c}57 \\
(14,0) \\
\end{array}$ & $\begin{array}{c}65 \\
(16,0) \\
\end{array}$ & $\begin{array}{c}222 \\
(54,7)\end{array}$ & 4,02 & 1,29 \\
\hline $\begin{array}{l}\text { 5. Uzaktan eğitimde muhasebe ders ve sınavlarında } \\
\text { geri bildirimlerden memnunum }\end{array}$ & $\begin{array}{c}33 \\
(8,1)\end{array}$ & $\begin{array}{c}35 \\
(8,6) \\
\end{array}$ & $\begin{array}{c}83 \\
(20,4) \\
\end{array}$ & $\begin{array}{c}77 \\
(19,0) \\
\end{array}$ & $\begin{array}{c}178 \\
(43,8)\end{array}$ & 3,81 & 1,300 \\
\hline $\begin{array}{l}\text { 6. Uzaktan eğitimde muhasebe derslerinde kendimi } \\
\text { geliştirdiğimi düşünüyorum }\end{array}$ & $\begin{array}{c}93 \\
(22,9)\end{array}$ & $\begin{array}{c}81 \\
(20,0)\end{array}$ & $\begin{array}{c}103 \\
(25,4)\end{array}$ & $\begin{array}{c}63 \\
(15,5)\end{array}$ & $\begin{array}{c}66 \\
(16,3)\end{array}$ & 2,82 & 1,376 \\
\hline $\begin{array}{l}\text { 7. Muhasebe eğitiminde uzaktan eğitim sürecinde } \\
\text { ögretim elemanı ile iletişim kurmanın daha hızlı ve } \\
\text { kolay olduğunu düşünüyorum. }\end{array}$ & $\begin{array}{c}73 \\
(18,0)\end{array}$ & $\begin{array}{c}73 \\
(18,0)\end{array}$ & $\begin{array}{c}100 \\
(24,6)\end{array}$ & $\begin{array}{c}69 \\
(17,0)\end{array}$ & $\begin{array}{c}91 \\
(22,4)\end{array}$ & 3,08 & 1,401 \\
\hline $\begin{array}{l}\text { 8. Uzaktan eğitim sistemi muhasebe derslerinin } \\
\text { ŏgrenimi açısından uygun bir eğitim sistemidir. }\end{array}$ & $\begin{array}{c}136 \\
(33,5)\end{array}$ & $\begin{array}{c}61 \\
(15,0) \\
\end{array}$ & $\begin{array}{c}92 \\
(22,7)\end{array}$ & $\begin{array}{c}50 \\
(12,3) \\
\end{array}$ & $\begin{array}{c}67 \\
(16,5) \\
\end{array}$ & 2,63 & 1,464 \\
\hline $\begin{array}{l}\text { 9. Uzaktan eğitim ile muhasebe derslerini tam } \\
\text { anlamıyla öğrendiğimi düşünmüyorum }\end{array}$ & $\begin{array}{c}52 \\
(12,8)\end{array}$ & $\begin{array}{c}67 \\
(16,5)\end{array}$ & $\begin{array}{c}98 \\
(24,1)\end{array}$ & $\begin{array}{c}64 \\
(15,8)\end{array}$ & $\begin{array}{c}125 \\
(30,8)\end{array}$ & 3,35 & 1,395 \\
\hline $\begin{array}{l}\text { 10. Uzaktan eğitimde muhasebe dersleri için zamanı } \\
\text { verimli kullanamadığımdan daha çok zaman } \\
\text { harcamaktayım }\end{array}$ & $\begin{array}{c}43 \\
(10,6)\end{array}$ & $\begin{array}{c}50 \\
(12,3)\end{array}$ & $\begin{array}{c}126 \\
(31,0)\end{array}$ & $\begin{array}{c}76 \\
(18,7)\end{array}$ & $\begin{array}{c}111 \\
(27,3)\end{array}$ & 3,39 & 1,293 \\
\hline $\begin{array}{l}\text { 11. Uzaktan eğitimde muhasebe derslerinde dikkat } \\
\text { dağınıklığı yaşıyorum }\end{array}$ & $\begin{array}{c}51 \\
(12,6)\end{array}$ & $\begin{array}{c}51 \\
(12,6)\end{array}$ & $\begin{array}{c}112 \\
(27,6)\end{array}$ & $\begin{array}{c}67 \\
(16,5)\end{array}$ & $\begin{array}{c}125 \\
(30,8)\end{array}$ & 3,40 & 1,366 \\
\hline $\begin{array}{l}\text { 12. Uzaktan eğitimde muhasebe derslerinde ders } \\
\text { videolarında konular zor ve karmaşık olmaktadır. }\end{array}$ & $\begin{array}{c}35 \\
(8,6) \\
\end{array}$ & $\begin{array}{c}52 \\
(12,8) \\
\end{array}$ & $\begin{array}{c}110 \\
(27,1) \\
\end{array}$ & $\begin{array}{c}91 \\
(22,4) \\
\end{array}$ & $\begin{array}{c}118 \\
(29,1)\end{array}$ & 3,50 & 1,268 \\
\hline $\begin{array}{l}\text { 13. Uzaktan muhasebe eğitim sürecinde dijital sistemi } \\
\text { kullanmakta zorluklar yaşamaktayım. }\end{array}$ & $\begin{array}{c}84 \\
(20,7)\end{array}$ & $\begin{array}{c}76 \\
(18,7)\end{array}$ & $\begin{array}{c}98 \\
(24,1) \\
\end{array}$ & $\begin{array}{c}60 \\
(14,8) \\
\end{array}$ & $\begin{array}{c}88 \\
(21,7)\end{array}$ & 2,98 & 1,426 \\
\hline $\begin{array}{l}\text { 14. Uzaktan eğitimde muhasebe dersleri ile ilgili } \\
\text { sorularımı ögretim elemanına soramadığımdan dolayı } \\
\text { zorluklar yaşıyorum }\end{array}$ & $\begin{array}{c}62 \\
(15,3)\end{array}$ & $\begin{array}{c}69 \\
(17,0)\end{array}$ & $\begin{array}{c}101 \\
(24,9)\end{array}$ & $\begin{array}{c}63 \\
(15,5)\end{array}$ & $\begin{array}{c}111 \\
(27,3)\end{array}$ & 3,22 & 1,408 \\
\hline $\begin{array}{l}\text { 15. Muhasebe eğitiminde uzaktan eğitim sürecinde } \\
\text { eğitim kalitesinin yüz yüze eğitime göre daha iyi } \\
\text { olduğunu düşünüyorum. }\end{array}$ & $\begin{array}{c}174 \\
(42,9)\end{array}$ & $\begin{array}{c}45 \\
(11,1)\end{array}$ & $\begin{array}{c}76 \\
(18,7)\end{array}$ & $\begin{array}{c}42 \\
(10,3)\end{array}$ & $\begin{array}{c}69 \\
(17,0)\end{array}$ & 2,47 & 1,529 \\
\hline $\begin{array}{l}\text { 16. Uzaktan muhasebe eğitim sistemi ile, muhasebe } \\
\text { geleceğime yönelik iş alanlarında yetersiz bilgiye sahip } \\
\text { olduğumu düşünüyorum. }\end{array}$ & $\begin{array}{c}43 \\
(10,6\end{array}$ & $\begin{array}{c}62 \\
(15,3)\end{array}$ & $\begin{array}{c}95 \\
(23,4)\end{array}$ & $\begin{array}{c}75 \\
(18,5)\end{array}$ & $\begin{array}{c}131 \\
(32,3)\end{array}$ & 3,46 & 1,356 \\
\hline $\begin{array}{l}\text { 17. Uzaktan muhasebe eğitimi, dijital okur yazarlık } \\
\text { alanında kendimi geliştirmem için bir firsat yarattı. }\end{array}$ & $\begin{array}{c}85 \\
(20,9) \\
\end{array}$ & $\begin{array}{c}67 \\
(16,5) \\
\end{array}$ & $\begin{array}{c}131 \\
(32,3)\end{array}$ & $\begin{array}{c}54 \\
(13,3) \\
\end{array}$ & $\begin{array}{c}69 \\
(17,0) \\
\end{array}$ & 2,88 & 1,344 \\
\hline $\begin{array}{l}\text { 18. Uzaktan eğitim sürecinde muhasebe derslerinde } \\
\text { problem çözme, eleştirel düşünme ve uygulama } \\
\text { becerilerimi geliştirdim. }\end{array}$ & $\begin{array}{c}84 \\
(20,7)\end{array}$ & $\begin{array}{c}68 \\
(16,7)\end{array}$ & $\begin{array}{c}131 \\
(32,3)\end{array}$ & $\begin{array}{c}64 \\
(15,8)\end{array}$ & $\begin{array}{c}59 \\
(14,5)\end{array}$ & 2,86 & 1,311 \\
\hline $\begin{array}{l}\text { 19. Uzaktan eğitim sürecinde muhasebe derslerinde } \\
\text { ödevlere ve sınavlara yönelik daha çok araştırma } \\
\text { yapmaktayım. }\end{array}$ & $\begin{array}{c}52 \\
(12,8)\end{array}$ & $\begin{array}{c}83 \\
(20,4)\end{array}$ & $\begin{array}{c}117 \\
(28,8)\end{array}$ & $\begin{array}{c}80 \\
(19,7)\end{array}$ & $\begin{array}{c}74 \\
(18,2)\end{array}$ & 3.10 & 1,279 \\
\hline
\end{tabular}

$*_{\mathrm{n}}=$ Katılımcı sayıc1; ${ }^{*} \mathrm{SD}=$ Standart Sapma; $*$ Ort=Ortalama 
Çalışmada ilk 5 ifade de (1-2-3-4-5) uzaktan eğitim sisteminin yüz yüze eğitime göre avantaj sağladığ 1 ifadeler yer almaktadır. Bu ifadeler aynı zamanda uzaktan muhasebe derslerinin "Güçlü” yanlarını göstermektedir. Katılımcıların verileri incelendiği zaman ilk 5 soruda da ifadelere "katılıyorum ve kesinlikle katılmıyorum" katılım oranlarının "katılmıyorum ve kesinlikle katılmıyorum" seçeneklerine göre daha fazla olduğunu göstermektedir. Uzaktan eğitim sisteminde muhasebe dersi ile ilgili olarak zaman ve mekân esnekliği (1) \%39,9, ders materyallerine ulaşım (2) \%46,8, ders materyal maliyetlerinde azalma (3) \%51, ders videolarının tekrar izlenebilmesi (4) \%70,7 ve ders ve sinavlarda geri bildirimin olması (5) \%62,8 olarak tespit edilmiştir.

Çalışmada diğer önemli bir nokta ise "Zayıf" yönlerin tespit edilmesidir. Bu amaçla çalışmada 9-10-11-12 ifadeleri yönlendirilmiştir. Uzaktan eğitimde muhasebe derslerini tam öğrenememe (9) \%46,6, zamanı verimli kullanamama (10) \%46,0, uzaktan eğitimde muhasebe derslerinde dikkat dağınıklığı olması (11) \%47,3 ve ders videolarının zor ve karmaşık olmasına (12) \%51,5 oranlarında katılım olduğu tespit edilmiştir.

Uzaktan eğitim sisteminde "Fırsat" olarak nitelendirilebilen ifadeler ise çalışmada 6-78-15-17-18 ve 19 siralı ifadelerinde bulunmaktadır. Katılımcılar bu firsat olarak belirtilen ifadelerden, uzaktan eğitimde muhasebe derslerinde kendini geliştirme (6) \%42,9, uzaktan eğitim ile muhasebe derslerinin uygun olması (8) \%48,5, uzaktan eğitimde ders kalitesinin yüz yüze eğitime göre daha iyi olması (15) \%54, Dijital okuryazarlık alanında kendini geliştirme (17) \%37,4 ve muhasebe derslerinde analitik düşünme becerilerinin geliştirilmesine (18) \%37,4 oranlarında bu ifadelere katılmadıklarını belirtmişlerdir. Ancak çıkan sonuçta sadece öğretim elemanı ile hızlı ve kolay iletişim kurabilme ifadesine (7) \%39,4 ve uzaktan eğitim sürecinde daha çok ödev ve sınavlarda araştırma yaptıkları ifadesine ise (19) \%37,9 oranında katıldıklarını ifade etmişlerdir.

Çalışma içerinde geriye kalan 13-14 ve 16. ifadeler ise katılımcıların uzaktan eğitim sistemindeki muhasebe derslerindeki "Tehdit" olarak belirtilen unsurları ölçmektedir. Katılımcılar uzaktan eğitimde dijital sistemini kullanmakta zorlanma (13) ifadesine \%39,4 oranında katılmadıklarını belirtmişlerdir. Ancak muhasebe derslerinde öğretim elemanına soru sorulamaması (14) \%42,8, muhasebe derslerindeki eğitim ile gelecekteki iş alanlarında yetersiz bilgiye sahip olunması (16) \%50,8 oranlarında katıldıkları tespit edilmiştir.

\subsection{Güvenilirlik Testi Ve Faktör Analizi}

Araştırmada elde edilen veriler doğrultusunda SPPS 15.0 programında ölçeğin güvenilirlik testi değeri incelendiği zaman Cronbach alpha değeri 0,805 değeri bulunmuştur. $\mathrm{Bu}$ değer $0.80 \leq \mathrm{p}<1.00$ aralığında yer aldığından dolayı yüksek güvenilirlik düzeyinde olduğunu göstermektedir. Aynı zamanda normallik testi yapıldığında çarpıklık (Skewness) ve basıklık (Kurtosis) değerleri +1 ve -1 değerleri (Hair vd., 2013) arasında olduğundan dolayı yapılan çalışmada veriler normal dağılmaktadır. 
Tablo 4. Faktörlerin Cronbach Alpha değerleri

\begin{tabular}{|c|c|c|}
\hline Boyut & İfadeler & $\boldsymbol{A}$ \\
\hline Güçlü & $1-2-3-4-5$ & $\mathbf{0 , 8 2 2}$ \\
\hline Zayıf & $9-10-11-12$ & $\mathbf{0 , 8 3 2}$ \\
\hline Firsat & $6-7-8-15-17-18-19$ & $\mathbf{0 , 8 8 7}$ \\
\hline Tehdit & $13-14-16$ & $\mathbf{0 , 7 8 5}$ \\
\hline
\end{tabular}

Tablo 4' de ölçekte bulunan ifadelerin gruplandırması 4 faktör boyutunda yapılmıştır. Bu boyutlara ait Cronbach alpha değerleri de çalışma açısından oldukça güvenilir bir düzeyde çıkmıştır.

\subsection{T Testi ve Anova Testi Sonuçları}

Çalışmada verilerin faktör boyutlarının bağımsız değişkenlere (cinsiyet, program türü, yaşanılan yer, muhasebe dersindeki başarı düzeyi, eğitime katıldıkları teknoloji türü) göre farklılıklarının tespiti açısından iki bağımsız değişken için $t$ testi, ikiden fazla bağımsız değişken için Anova testleri uygulanmıştır. Anova testlerinin anlamlı çıkması durumunda ise yorumlama yapabilmek için Tukey testinden yararlanılmıştır. Cinsiyete göre yapılan $t$ testi analiz sonuçları aşağıdaki tabloda düzenlenmiştir.

Tablo 5. Katılımcıların Uzaktan Eğitim Sisteminde Muhasebe Derslerine Göre Cinsiyete Göre t-Testi Sonuçları

\begin{tabular}{|lllllc|}
\hline Boyut & Cinsiyet & n & Ort. & t & P \\
\hline \multirow{2}{*}{ Güçlü } & Kadın & 209 & 3,4641 & 1,502 & 0,134 \\
& Erkek & 197 & 3,6193 & & \\
Zayıf & Kadın & 209 & 3,4414 & 0,526 & 0,599 \\
& Erkek & 197 & 3,3871 & & \\
Fırsat & Kadın & 209 & 2,6610 & 3,467 & $\mathbf{0 , 0 0 1}$ \\
\multirow{2}{*}{ Tehdit } & Erkek & 197 & 3,0261 & & \\
& Kadın & 209 & 3,2887 & 1,208 & 0,228 \\
\hline
\end{tabular}

Katılımcıların uzaktan eğitim sisteminde yer alan firsat faktöründe kadın ve erkek arasında anlamlı bir korelasyon $(p>0,05)$ saptanmıştır. Ortalamalar dikkate alındığında erkekler kadınlara göre uzaktan eğitim sistemini firsat olarak görmektedir. Ancak diğer alt faktörlerde benzer bir farkl1lık görülmemektedir.

Çalışmaya katılanlar lisans ve ön lisans öğrencilerden oluşmaktadır. İki programın öğrencilerinin uzaktan eğitim sisteminde muhasebe eğitimine yönelik algıları $t$ testi analizi sonucunda aşağıdaki tabloda ele alınmıştır. 
Tablo 6. Katılımcıların Uzaktan Eğitim Sisteminde Muhasebe Derslerindeki Algılara Yönelik Öğrenim Programlarına Göre t-Testi Verileri

\begin{tabular}{|lllllc|}
\hline Boyut & Program & n & Ort. & t & P \\
\hline \multirow{2}{*}{ Güçlü } & Lisans & 216 & 3,6259 & 1,788 & 0,74 \\
& Ön lisans & 190 & 3,4411 & & \\
Zayıf & Lisans & 216 & 3,5081 & 1,932 & 0,54 \\
& Ön lisans & 190 & 3,3092 & & \\
Firsat & Lisans & 216 & 2,8651 & 0,540 & 0,590 \\
& Ön lisans & 190 & 2,8075 & & \multirow{2}{*}{,011 } \\
Tehdit & Lisans & 216 & 3,3549 & 2,550 & \\
& Ön lisans & 190 & 3,0754 & & \\
\hline
\end{tabular}

Elde edilen sonuçlarda "Tehdit" faktörüne lisans öğrencileri önlisans öğrencilerine göre daha fazla katılmaktadır. Bunun sebebinin ise lisans mezunu öğrencilerin önlisans öğrencilerine göre ara eleman olmaktan daha çok uzmanlık sınavları ve kariyer yollarının açık olmasından kaynaklı olduğu düşünülebilir.

Katılımcıların yaşadıkları yer ile çalışmadaki faktörler arasındaki ilişki incelendiği zaman uzaktan eğitim sisteminde muhasebe derslerinin il ve köy de yaşayanlar arasında anlamlı bir farklılık olduğu tabloda belirtildiği üzere Anova analizi sonucu $(p<0,05)$ görülmektedir.

Tablo 7. Katılımcıların Yaşanılan Yere Göre Ölçek Faktörlerinin Tek Yönlü ANOVA Analizi ile Değerlendirilmesi

\begin{tabular}{|llllllll|}
\hline Boyut & Yaşanılan Yer & Sayı(N) & Ort.(X) & SS & F & P & $\begin{array}{l}\text { Anlamlı } \\
\text { Fark }\end{array}$ \\
\hline \multirow{2}{*}{ Güçlü } & İl & 233 & 3,639 & 1,031 & 4,458 & $\mathbf{0 , 0 1 2}$ & İl-Köy \\
& İlçe & 83 & 3,563 & 1,005 & & & \\
& Köy & 90 & 3,257 & 1,063 & & & \\
Toplam & 406 & & & & & \\
\hline
\end{tabular}

Elde edilen veriler 1şı̆̆ında Tukey testi sonucunda ise, illerde yaşayan öğrenciler uzaktan eğitim sisteminde muhasebe derslerinin güçlü yönlerine köyde yaşayanlara göre daha çok katılmaktadırlar.

Öğrencilerin başarı düzeyleri ve çalışmada yer alan faktörler arasındaki ilişski incelendiği zaman Anova testinde Güçlü ve Fırsat boyutunda $\mathrm{p}<0,05$ olduğundan tabloda görüldüğü gibi anlamlı bir farklılık çıkmıştır.

Tablo 8. Katılımcıların Başarı Düzeyine Göre Ölçek Faktörlerinin Tek Yönlü ANOVA Analizi ile Değerlendirilmesi

\begin{tabular}{|llllllll|}
\hline Boyut & Başarı Düzeyi & Sayı(N) & Ort.(X) & SS & F & P & Anlamlı Fark \\
\hline \multirow{2}{*}{ Güçlü } & Başarısız & 50 & 3,0080 & 1,248 & 4,801 & $\mathbf{0 , 0 0 1}$ & Başarısız ve diğerleri \\
& Ş.Başarılı & 70 & 3,5629 & 0,893 & & & \\
& Orta & 162 & 3,5827 & 0,986 & & & \\
& İyi & 87 & 3,7862 & 0,960 & & &
\end{tabular}




$\begin{array}{|llllllll|} & \text { Pekiyi } & 37 & 3,4432 & 1,203 & & & \\ & \text { Toplam } & 406 & & & & & \\ \text { Fırsat } & \text { Başarısız } & 50 & 2,2371 & 1,002 & 5,014 & \mathbf{0 , 0 0 1} & \text { Başarısız ve diğerleri } \\ & \text { S.Başarıl1 } & 70 & 2,7980 & 1,015 & & & \\ & \text { Orta } & 162 & 2,9453 & 1,012 & & & \\ & \text { İyi } & 87 & 2,9885 & 1,096 & & & \\ & \text { Pekiyi } & 37 & 2,9035 & 1,228 & & & \\ & \text { Toplam } & 406 & & & & \end{array}$

Oluşan farklılığın başarı düzeylerinde değerlendirilmesi amacı ile Tukey testinden yararlanılmıştır. Sonuç olarak, uzaktan eğitimde muhasebe derslerinin güçlü ve fursat yönlü ifadelerine, başarısız öğrencilerin katılımı diğer başarı düzeyindeki öğrencilere göre daha az olmuştur.

Elde edilen veriler sonucunda bilgisayar ve cep telefonunu arasinda da anlaml farkl111klar görülmektedir.

Tablo 9. Katılımcıların Eğitime Katıldıkları Ulaşım Teknolojilerine Göre Ölçek Faktörlerinin Tek Yönlü ANOVA Analizi ile Değerlendirilmesi

\begin{tabular}{|lllcllll|}
\hline Boyut & Eğitime Ulaşım & Sayı(N) & Ortalama(X) & SS & F & P & Anlamlı Fark \\
\hline \multirow{2}{*}{ Güçlü } & Bilgisayar & 145 & 3,7117 & 0,913 & 3,317 & 0,037 & Bilg.-cep tel \\
& Tablet & 11 & 3,6364 & 1,182 & & & \\
& Cep telefonu & 250 & 3,4352 & 1,095 & & & \\
& Toplam & 406 & & & & & \\
& & & & &
\end{tabular}

Verilerin değerlendirilmesi sonucunda Cep telefonu ile derslere katılan öğrenciler, bilgisayarla katılan öğrencilere göre uzaktan eğitim sisteminin muhasebe derslerindeki güçlü yönlerine daha az katılmaktadır.

\subsection{Katılımcıların Uzaktan Muhasebe Eğitimine Yönelik Görüşleri}

Çalışmanın son sorusu katılımcıların görüşlerini alabilmek amaçlı açık uçlu olarak belirlenmiştir. Elde edilen veriler de olumlu ve olumsuz görüşlerin olduğu görülmektedir. Uzaktan eğitimde muhasebe derslerinin olumsuz yönlerine ait görüşlerin ortak ifadeleri şu şekilde özetlenebilir;

"Sadece sınav zamanı konular çok olduğu için hangilerinin üstünde çok durmam gerektiğini bilemiyorum”.

"Sınıf ortamını ve ciddiyetin olmadiğg yerde eğitimin kalitesinin düştüğüne inaniyorum."

"Konuları her ne kadar anlasam da takıldı̆̆ım kısımlar çok oluyor, takıldı̆̆ım ya da anlamadığım kısmı hocamıza soramıyorum videoyu tekrar tekrar başa sarmak durumunda kallyorum"

"İlk başlarda sisteme alışık olmadı̆̆ım için zorluklar yaşadım."

"Uzaktan eğitim sistemiyle dersi anlamakta, derse odaklanmakta zamanı disiplinli bir şekilde kullanmakta, takıldiğım yeri anlamakta güçlük çekiyorum. Ders işlenen bu haftalar içerisinde yeterli bilgiye sahip olduğumu düşünmüyorum. Dersi 
geçiyorsam kendi bilgilerimle değil kişi ve kaynaklardan aldĭ̆ım yardımla geçebiliyorum. Bilgilerim yeterli değil uzaktan ĕgitimle bu ders ve birçok ders verimli değil zor zorlayıcı olmaktadır"

"Olumsuz yönleri daha fazla çünkü evde okul ortamı yaratamıyoruz zamanında derslere katılamıyoruz ve yüz yüze eğitim gibi verim alamıyoruz."

"Muhasebe dersine tam hâkim olamiyorum uzaktan eğitim sebebiyle internet sayesinde araştırma yaparak öğrenebiliyorum ve videoları tekrar izleyerek"

"Bulunduğum köyde internet bulunmamaktadır. Sinav haftast sadece çalışabiliyorum. Verim alamıyorum."

"Geleceğe yönelik planlarıma baktı̆̆ım zaman yeterince kendimi geliştiremediğimi, bilgi edinemediğimi düşünüyorum. Uzaktan ĕ̌itim ile de gelecekte ki hayallerimi yaşamakta zorlanacağımı düşünüyorum”

Olumsuz görüşlerin genelinde derste soru sormakta zorluk çekme, sınıf ortamında yaratılan disiplinin ev ortamında yapılamaması, internet sıkıntısı yaşanması, zaman yönetimindeki sıkıntılar göze çarpmaktadır. Bu olumsuzluklara rağmen yeni eğitim düzeninin olumlu taraflarını katılımcılar aşağıdaki ifadelerde açıkça belirtmiştir.

"Uzaktan ĕgitim bu süreçte hocalarımızı görmesek dahi iletişim kurabiliyoruz mesajlarımıza çabuk cevap veriliyor hocalarımızla güzel bir iletişimimiz var"

"Daha iyi dersi dinleyebiliyorum ve hocamızın güzel anlatımıyla dersi rahat bir şekilde anlayabiliyorum sorun yaşamıyorum ve bu dersi görmekten çok mutluluk duyuyorum"

"Olumlu yanı çalışma zamanı bol olması"

"Illk defa muhasebe dersi görmeme răgmen çok sıkıcı değil. Bana muhasebe dalında bazı bilgiler kattığını düşünüyorum.”

"Olumlu yönü sınavlara ve ödevleri yaparken araştırma yaptığımız için daha çok bilgi ögrenebiliyoruz”

"Videoları tekrar izleyerek konuyu tekrar pekiştirmemi sağladı"

"Düzenli gidip geldiğim bir iş hayatı olduğu için uzaktan eğitimin yararıma olduğunu düşüyorum.”

\section{SONUÇ}

Bu çalışmada, muhasebe derslerinin uzaktan eğitim ile verilmesinin güçlü, zayıf, fırsat ve tehdit oluşturan unsurlarının tespiti ve katılımcıların demografik özelliklerine göre etkileri ele alınmıştır. Sonuç olarak, katılımcıların çalışma içerisinde bulunan 4 faktörden "Güçlü” ve “Zayıf” Boyutlarında yer alan ifadelere çoğunluğun katılım gösterdiği tespit edilmiştir. Ancak genel olarak uzaktan eğitimde firsat olarak değerlendirilebilecek unsurların, uzaktan eğitimde muhasebe derslerinde kendini geliştirme, muhasebe derslerinin uzaktan eğitime uygun olması, ders kalitesinin yüz yüze eğitime göre daha iyi olması, dijital okuryazarlık alanında kendini geliştirme, muhasebe derslerinde analitik düşünme becerilerinin geliştirilmesi yönündeki ifadelere olumlu yönde katılım olmamıştır. Sadece öğretim elemanı ile hızlı ve kolay iletişim kurabilme ifadesine ve uzaktan eğitim sürecinde daha çok ödev ve sınavlarda araştırma yaptıkları ifadelerine olumlu yönde katılım sağlamışlardır. Tehdit olarak algılanabilecek dijital sistem kullanımı öğrenciler için bir sorun oluşturmadığı sadece eğitim ile ilgili öğretim elemanına soru sormakta zorlanma ve dolayısıyla yetersiz bilgi ile gelecekte iş alanlarında sorun yaşanacağı yönünde görüşler tespit edilmiştir. 
Çalışma içerisinde muhasebe eğitiminin uzaktan verilmesi ile birlikte fursat olarak ortaya çıkan durumlarda cinsiyete göre farklılık yarattığı görülmüştür. Elde edilen verilerde kadın öğrencilerin pandemi sürecini erkek öğrencilere göre firsata dönüştüremediğini göstermektedir.

Katılımcıların yaşadıkları yerin değerlendirilmesi yapıldığında, uzaktan eğitim sisteminde muhasebe derslerinin güçlü yönlerine köyde yaşayan öğrencilerin ilde yaşayanlara göre daha az katılım sağladıkları tespit edilmiştir. Öğrenci görüşlerinde ortaya çıkan bu durum, köyde internet alt yapısındaki yetersizlik nedeniyle eşit eğitim hakkından bazı öğrencilerin yararlanamadığını göstermektedir.

Muhasebe derslerindeki başarı düzeylerine göre katılımcılar incelendiğinde ise, uzaktan eğitim sisteminde muhasebe derslerinde başarılı olmayan öğrencilerin sistemin getirdiği güçlü yönleri ve fırsatları başarılı öğrenciler kadar yeterli düzeyde kullanamadıkları tespit edilmiştir.

$\mathrm{Bu}$ süreçte yaşanan birçok olumsuzluklara rağmen sistemin yaratmış olduğu güçlü ve firsat yönlerin varlığından söz edebiliriz. Ancak bunun yanında tespit edilen zayıf ve tehdit yönlerinin üniversiteler ve öğretim elemanları tarafından dikkate alınarak sistem içerinde çözümler üretmesi gerekmektedir. Her bir öğrencinin eğitimden eşit yararlanması ve bu haklardan yoksun bırakılmaması üniversitelerin temel amacı olmalıdır.

\section{KAYNAKLAR}

Afşar, Bilge- Büyükdoğan, Birol (2020), “Covıd-19 Pandemisi Döneminde İİBF ve SBBF Öğrencilerinin Uzaktan Eğitim Hakkındaki Değerlendirmeleri.” Karatay Sosyal Araştırmalar Dergisi, (5), ss.161-182.

Akgün, Ali İhsan (2020), “COVID-19 Sürecinde Acil Durum Uzaktan Eğitimi Yoluyla Verilen Muhasebe Eğitimine Yönelik Öğrenci Görüşleri”, Açık öğretim Uygulamaları ve Araştırmaları Dergisi,6(4), ss.208-236

Aydın, Cengiz Hakan (2011), “Açık ve Uzaktan Öğrenme: Öğrenci Adaylarının Bakış Açısı” Ankara Pegem akademi, ss.52-68

Ayyıldız, Sema Ülker- Günlük, Mehmet- Erbey, Senem Nil (2006), “Muhasebe Öğretim Elemanlarının Uzaktan Eğitim ve Uzaktan Muhasebe Eğitimine Yönelik Tutumları Üzerine Bir Araştırma”, Muhasebe ve Finansman Dergisi (MUFAD), (32), ss.1-14 .

Bhuasiri, Wannasiri- Xaymoungkhoun, Oudone - Zo, Hangjung - Rho, Jae jeung - Ciganek, Andrew P. (2012), "Critical Success Factors For E-Learning in Developing Countries: A Comparative Analysis Between ICT Experts and Faculty”, Computers and Education, 58(2), pp. 843-855.

Can, Ertuğ (2020), “Coronavirüs (Covid-19) Pandemisi ve Pedagojik Yansımalar1: Türkiye'de Açık ve Uzaktan Eğitim Uygulamaları", Açık öğretim Uygulamaları ve Araştırmaları Dergisi, 6(2), ss.11-53. 
DeLone, William. H.- McLean, Ephraim R. (1992), "Information Systems Success: The Quest For The Dependent Variable”, Information Systems Research, 3(1), pp.60-95.

Dhawan, Shivangi (2020), “Online Learning: A Panacea in the Time of COVID-19 Crisis”, Journal of Educational Technology Systems, 49(1), pp.5-22.

Hair, Joseph F - Black, Bill- Babin, Barry. J., Anderson, Rolph E., \& Tatham, R. L. (2013), Multivariate Data Analysis: Pearson Education Limited.

Karadağ, Engin- Yücel, Cemil (2020), "Yeni Tip Koronavirüs Pandemisi Döneminde Üniversitelerde Uzaktan Eğitim: Lisans Öğrencileri Kapsamında Bir Değerlendirme Çalışması", Yükseköğretim Dergisi, 10 (2), ss.181-192 .

Kırık, Ali (2016), "Uzaktan Eğitimin Tarihsel Gelişimi ve Türkiye’deki Durumu", Marmara İletişim Dergisi 0 (21), ss. 73-94.

Kurnaz, Ersin- Tekbaş, İsmail- Bozdoğan, Tunga- Çetin, Ömer Orbay (2020), "Dijitalleşmeyle Birlikte Muhasebe Eğitiminin Muhasebe Meslek Mensupları Açısından Değerlendirilmesi”, Muhasebe Bilim Dünyası Dergisi, MODAV 16. Uluslararası Muhasebe Konferansı Özel Sayısı, ss.81-96

Kurnaz, Ersin- Serçemeli, Murat (2020), “Covid-19 Pandemi Döneminde Akademisyenlerin Uzaktan Eğitim ve Uzaktan Muhasebe Eğitimine Yönelik Bakış Açıları Üzerine Bir Araştırma”, Uluslararası Sosyal Bilimler Akademi Dergisi, (3), ss. 262-288

Nizam, Feridun (2004), “Eğitim-Öğretimde Kitle İletişim Araçlarının Kullanım Olanakları ve Avantajları", KATÜ Akademik Bilişim, ss.1-17.

Özan, Mukadder Boydak- Polat, Hakan - Gündüzalp, Seda - Yaraş, Zübeyde (2015), "Eğitim Kurumlarında SWOT Analizi”, Turkish Journal of Educational Studies, 2(1), ss. 1-28.

Serçemeli, Murat- Kurnaz, Ersin (2020), “Covid-19 Pandemi Döneminde Öğrencilerin Uzaktan Eğitim ve Uzaktan Muhasebe Eğitimine Yönelik Bakış Açıları Üzerine Bir Araştırma”, Uluslararası Sosyal Bilimler Akademik Araştırmalar Dergisi, 4 (1), ss. 4053

Stoller, James K. (2020), "A Perspective on the Educational "SWOT" of the Coronavirus Pandemic”, Chest Journal, 159 (2), pp.743-748

Weihrich, Heinz (1982), “The TOWS Matrix-A Tool For Situational Analysis”, Long Range Planning, 15 (2), pp. 54-66.

Yardımcıŏglu, Mahmut- Şıtak, Başak- Yörük, Ali (2021). “Meslek Yüksekokulu Öğrencilerinin Muhasebe Eğitimine Karşı Tutumlarının COVID-19 Pandemi Döneminde İncelenmesi”, Uluslararası Sosyal Bilimler ve Eğitim Dergisi, 3 (4), ss. 155-180.

Yükseköğretim Kalite Kontrol (YOKAK). https://portal.yokak.gov.tr/makale/uzaktan-egitimve-kalite-guvence-sistemi/ (25 Şubat 2021). 
